\title{
The Young of the Gobiidæ from the Neighbourhood of Plymouth.
}

\author{
By
}

Marie V. Lebour, D.Sc.

Naturalist at the Plymouth Laboratory.

With 4 plates and 3 figures in the text.

\section{CONTENTS}

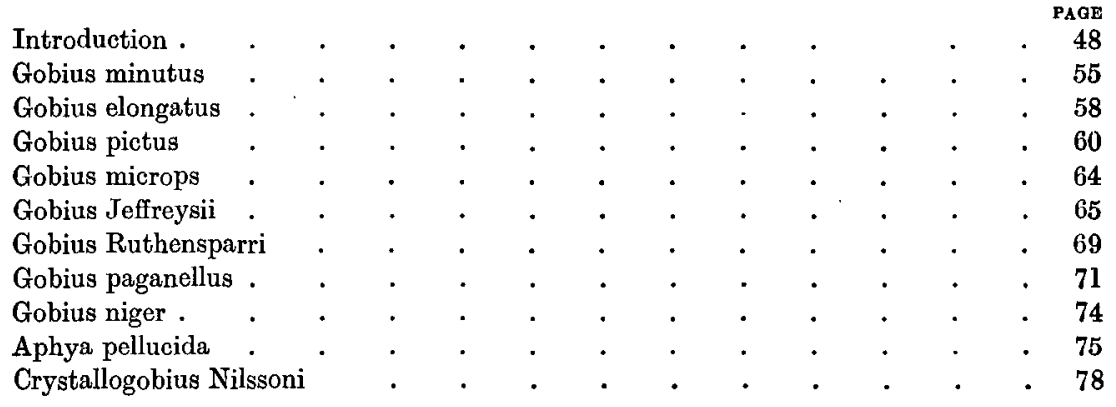

For reference to C. G. J. Petersen's recent work on gobies (1919) see page 146.

\section{INTRODUCTION.}

Several Gobius species and also Aphya and Crystallogobius are common near Plymouth, from up the estuaries in the neighbourhood of Saltash to the west and Chelson Meadow to the east, as far as the open sea, well beyond Rame Head and the Eddystone Lighthouse. It has, however, always been difficult to determine the young of the various species as they usually differ very little from one another and it is hoped that the following notes may be a help in the elucidation of the subject.

It has been found that although the differences in the young are not great yet they are usually constant and, in cases where the adults have been regarded as different forms only of one species, the young differ in certain characters from one another and can be separated fairly easily. This is the case with Gobius minutus and microps and the deep water form of minutus which is probably the form norvegicus of Collett (1902), and in this paper is regarded as Gobius elongatus. These 
three were regarded by Holt and Byrne (1901) as distinct forms of Gobius minutus having different habitats; microps being the estuarine form, minutus proper living near the shore but not penetrating far up the estuaries, and the deep water form always living further out. Petersen (1917) is doubtful about minutus and microps being separate species and describes the young together as Gobius minutus, although Boulenger (1911) definitely separates them. Fage (1914, 1915 and 1918) .shows that $G$. minutus and microps can be distinguished easily by the very different arrangement of the sensory papillæ, and that Gobius elongatus of Canestrini differs from minutus also by the arrangement of the papillæ, although it is very much nearer the arrangement in minutus than in microps. For this reason and because of other small differences he separates $G$. elongatus from minutus and regards it as a species representing minutus in the Mediterranean. On examination of the deep water form of minutus round about Plymouth, it is seen to agree with Canestrini's description of elongatus and to differ from the inshore form of minutus in number of vertebræ and fin rays, and also in the arrangement of the sensory papillæ which agree with that of elongatus as described by Fage.

The young stages of these three forms are quite distinct and differ from one another in number of vertebræ, number of fin rays and in pigmentation, so that they are usually easily recognisable. Variation in the number of vertebræ and fin rays occurs only rarely, the typical number being very nearly constant. It seems therefore that one is as much justified in regarding these three as separate species as one is in regarding Gobius pictus as distinct, this species having closer relationship with microps than microps has with minutus. The natural grouping seems to be to regard Gobius minutus and elongatus as two closely related species, and G. microps and pictus as two closely related species. Each group separated distinctly in the adults by the type of arrangement of the sensory papillæ (Fage op. cit.).

The most estuarine species is Gobius microps. The young are caught in the Sound in the tow-nets within and more rarely outside the Breakwater, and the adults occur in the estuaries, notably in Chelson Meadow where the water is brackish or frequently nearly fresh. Gobius niger also occurs in the estuaries (Holt and Byrne, 1901), but the young besides occurring in the Sound are also found beyond Rame Head and the Eddystone. Aphya pellucida is recorded from the Lynher River and the Tamar (Holt, 1897), but is more frequently found further from the shore.

Near the shore Gobius minutus and Gobius pictus occur and frequently Gobius Ruthensparri is caught with these, but the latter fish lives near the surface and not at the bottom. The young of all these are found in the Sound, but whereas Gobius minutus appears never to be far from the 
shore, Gobius pictus may be found in the open water beyond Rame Head at about 25 to $30 \mathrm{~mm}$., and the adults are also found in the more open water as well as inshore. In the Sound the young of Gobius Ruthensparri are frequently taken by the tow-nets, but not far out to sea.

Gobius paganellus is very common under stones at the level of the lowest spring tides. The young are caught in the tow-nets in the Sound both inside and outside the Breakwater and occasionally occur further out.

The species of young Gobius found commonly in the deeper water are Gobius elongatus and Gobius Jeffreysii, Gobius elongatus taking the place of $G$. minutus, which does not occur so far out. The young Gobius Jeffreysii are often obtained with those of $G$. elongatus in the deeper water beyond Rame Head and the Eddystone. These are the most striking of all the young gobies, as they are much pigmented and develop into the bottom stage very early.

Gobius scorpioides has only been obtained very rarely and its young stages have not as yet been noticed in this district.

Crystallogobius Nilssoni occurs frequently in the more open water; but the very young are not often obtained.

We thus have 9 species of Gobius occurring in the neighbourhood of Plymouth, and also Aphya pellucida and Crystallogobius Nilssoni. Of these all the young have been obtained with the exception of Gobius scorpioides.

In identifying the young gobies the vertebræ and fin formulæ are the most valuable points of difference as the scales and sensory papillæ are not developed until the later stages. In fresh specimens the vertebræ and fin rays can be readily counted. General form and pigment are also of importance, especially in preserved specimens, where in order to count the vertebræ one has to employ special methods. The size of the eye is also a useful guide, especially in two species where the number of vertebræ is the same (e.g. G. elongatus and G. Ruthensparri). The position of the air bladder very near the anus is distinctive of Aphya and Crystallogobius.

The number of vertebræ and fin rays are usually very constant characters, in only very few cases overlapping. The use of the arrangement of papillæ on the head and body as employed by Sanzo (1911) and Fage $(1914,1915,1918)$ is valuable for the young which have attained a certain size, but of no use for the very young, for, as Fage himself shows, these do not attain their full development in the young and frequently, even if developed, differ in many respects from the adults. For half-grown fish or even less the papillæ form a valuable guide to the species. For showing up the papillæ the method of Sanzo (1911) was used, the specimens being first soaked in alcohol, then in a $2 \%$ solution of chromic acid for about 24 hours. 
For the preserved material the vertebræ and fin rays were examined by staining with alizarin : a very dilute solution acting for a fairly long period giving the best results. In counting the vertebræ the first with a spine is counted as one, the curved portion at the tail end being counted as the last (Fig. 1).

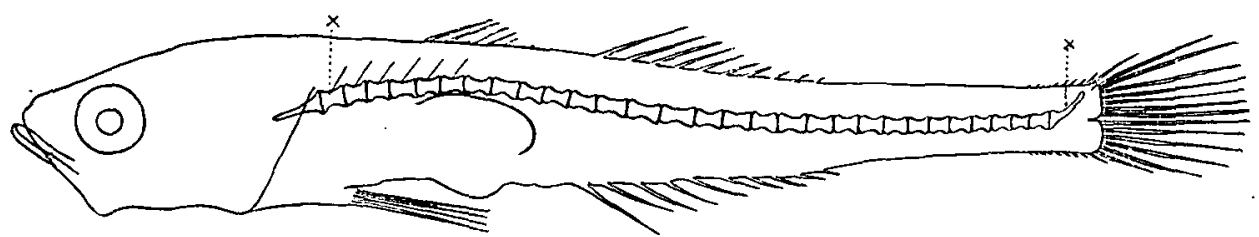

Fro. 1.-Diagram showing vertebra; the crosses indicate the first and last vertebræ counted.

Gobius minutus possesses the largest number of vertebræ, nearly always 33 , rarely 34 , very rarely 32 .

Gobius elongatus has 32 vertebræ, very rarely 33,31 or even 30 (those with 31 and 30 not being quite certainly identified).

Gobius Ruthensparri has also 32 vertebræ.

Gobius microps has 31 vertebræ, rarely 30.

Gobius pictus has 30 vertebræ, rarely 29.

Gobius Jeffreysii has 30 vertebræ, constant in all those examined.

Gobius paganellus has 28 vertebræ, rarely 29.

Gobius niger also has 28 vertebræ, rarely 29 .

Crystallogobius Nilssoni has usually 30 vertebræ, rarely 29 .

Aphya pellucida has 27 vertebræ, a smaller number than any of the gobies here described.

The fins are perhaps even more valuable as differentiating characters as they can often be counted without any special preparation. The first dorsal, which is not developed in the very young, usually contains 6 rays and, as shown by Petersen (1917) for Gobius minutus, in those with 6 rays the 6th ray is further away from the 5th than those in front are from one another (Fig. 2A). 6 rays occur thus in Gobius minutus, microps, pictus, elongatus, Jeffreysii, paganellus and niger. In $G$. Ruthensparri, which has 7 rays; the first 6 are close together, the 7 th further back (Fig. 2B). When, as is exceptionally the case in $G$. minutus or elongatus, any of the others have 7 rays, the 6 th may be as usual far
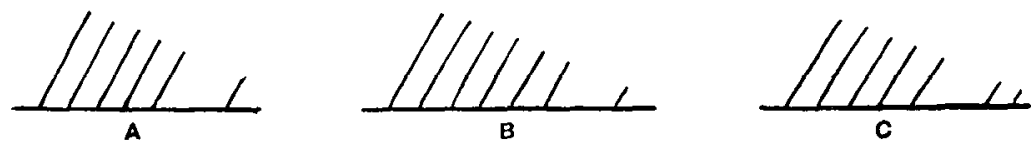

Frg. 2.-Diagram of first dorsal fin.
A. Gobius minutus and others with 6 rays (typical).
B. Gobius Ruthensparri.
C. Gobius elongatus, variety with 7 rays. 
away from the 5th, the 7 th being closer to the 6th (Fig. 2C), or the arrangement may be as it is in $G$. Ruthensparri.

Aphya pellucida has 5 rays, the same distance apart, but these do not appear for a long time and may still be absent at about $18 \mathrm{~mm}$. In Crystallogobius Nilssoni the first dorsal is absent in the female and there are only two rays in the male which appear very late.

The second dorsal contains 11-12 rays in Gobius minutus and so also does the anal. In none of those examined were there less, and this agrees with Fage (1918) and Boulenger (1911). Gobius elongatus, microps, pictus and Jeffreysii have 9-10, usually 10, G. elongatus occasionally having 11 , but never 12, which is the more usual number in minutus. Gobius Ruthensparri has 10-11, nearly always 11. Gobius paganellus 13-15, anal 11-13; Gobius niger 13-14, usually 13, anal 11-13, usually 12. Aphya pellucida has 12-13, anal 14; Crystallogobius Nilssoni has 19-20, anal 21. It is thus seen that whereas Aphya and Crystallogobius have usually a larger number of rays in the anal than in the dorsal fin [Fage (1918) gives an equal number for Aphya], in Gobius these are usually either equal or there are more rays in the dorsal. Variations in $G$. minutus sometimes occur having one more ray in the anal than in the dorsal fin.

Gobius minutus can be distinguished from those which resemble it closely by its vertebræ and fins, the species nearest it being $G$. elongatus, but whose habitat is always in deeper water than G. minutus. Gobius Ruthensparri can be distinguished from elongatus by its almost uninterrupted ventral chromatophores from anus to tail and later on by its first dorsal fin which appears after about $10 \mathrm{~mm}$. Gobius microps, pictus and elongatus are most easily differentiated by the number of vertebræ when very young, G. pictus and Jeffreysii both typically having 30 vertebræ. The young of $G$. Jeffreysii, however, is easily distinguished from pictus by its heavier build, much more intense pigmentation and earlier development of fins with longer fin rays. Of the others $G$. elongatus and pictus are the most easily mixed as they have very little pigmentation up to a late stage and forms which are apparently varieties of elongatus sometimes occur having some of the characters of pictus. As a rule, however, $G$. elongatus has 32 vertebræ, is found in deeper water than pictus and never comes so near inshore; G. pictus has 30 vertebræ, sometimes 29 , and although it sometimes occurs in deep water both the young and adults are more commonly found inshore. Gobius microps having 'typically 31 vertebræ differs from both in its young stages by its intense pigmentation and occurs only near the coast and up the estuaries. Never in deep water like G. elongatus.

Gobius niger and paganellus have the same number of vertebræ, usually 28 , but besides a difference in fin rays, $G$. niger has much more 
pigment than paganellus and develops into the bottom form at a much smaller size. It occurs in deeper water than paganellus although it also occurs in the Sound and up the estuaries.

Aphya and Crystallogobius can be distinguished from the Gobius species in their young stages by their very slender form, slight pigmentation and extremely slow development of the paired fins, besides the position of the air bladder very near the anus. The Gobius most easily confused with Aphya in the young stages is G. paganellus with its slender form and slight pigmentation, but it is always less slender and more pigmented than Aphya and can be distinguished from it by the development of the fins and the position of the air bladder besides the additional vertebra. Crystallogobius having so many more fin rays in the dorsal and anal fins cannot be confused with any of the other species.

The paired fins are developed in varying degrees in the different species, being much the most backward in Aphya and Crystallogobius. The pectorals are in most cases omitted in the figures as they usually show little in side view except when very well developed as in Gobius Jeffreysii or in the later stages. The pelvics, however, vary much in their length and state of development in the different species and are useful in differentiating them. Thus in G. Ruthensparri they are only very slightly developed at $12 \mathrm{~mm}$., whilst in $G$. elongatus of the same size they reach to nearly the end of the air bladder.

It is only in the older stages that any use can be made of the arrangement of the sensory papillæ as a distinguishing character, but specimens of $G$. elongatus of $18 \mathrm{~mm}$. show certain distinctive characters, and in G. Jeffreysii at $16 \mathrm{~mm}$. although they are not quite of the adult form yet they show that they belong to that type. Specimens of G. pictus of $23 \mathrm{~mm}$. show the adult characters in the sensory papillæ so that they can be distinguished from microps, to which species they bear a close resemblance.

Of the work on young gobies beyond the newly hatched forms the most detailed is that by Petersen (1917) who distinguishes between all stages of Gobius Ruthensparri, Gobius niger and Gobius minutus and microps together. The two latter are described as one species although two forms are recognised which agree with Gobius minutus proper and Gobius microps as distinguished by Boulenger (1911). The two forms are, however, not differentiated in the descriptions of the young, and most of the figures are almost certainly of microps. Fage (1918) describes from off Brest young gobies which he refers to minutus, but these possess $30-31$ vertebræ, and the figure given shows pigment which differs from our specimens in being more profuse on the head, with a chromatophore behind the head dorsally and one behind the first dorsal fin, also two large ramifying dorsal chromatophores on the tail corresponding to two 
similar chromatophores ventrally. The pigmentation and proportions are more like our post-larval $G$. Jeffreysii than minutus. Ehrenbaum and Strodtmann (1904) describe and figure young Gobius niger from the Baltic which are very similar to those from open water near Plymouth, and these are probably the form as differentiated by Fage (1915) which are larger than Gobius niger proper and undergo metamorphosis at a larger size. Collett (1877) refers to the young of Aphya and Crystallogobius and Ehrenbaum (1905) gives original drawings of the later postlarval stages of these, besides describing several of the young Gobius. Other descriptions chiefly refer to the eggs and newly hatched young, those of special importance being by Guitel (1892) and Petersen (1910). Hefford (1910) describes the egg and newly hatched young of Gobius paganellus, but beyond this stage the young of this species have apparently remained undescribed. The young Gobius Jeffreysii, pictus and elongatus are also described here for the first time and the young Gobius minutus and microps distinguished and separated.

The material worked on was from the hauls with the Young Fish Trawl made by Clark in 1913 and 1914 from the neighbourhood of Plymouth [Clark (1913), Allen (1917)], and also from tow-nettings made throughout the year 1918 in Plymouth Sound, together with some odd bottled specimens from the same localities. For the various parts of the Sound and outside, reference should be made to the chart by Clark (1913) and the plan of the Sound by Lebour (1918). A few specimens from the tow-nets were kept alive in small aërated aquaria (see page 9 of this Journal), and by this means Gobius Ruthensparri and Gobius microps were reared to a stage at which it was impossible to mistake the species.

The eggs of Gobius paganellus were reared and hatched out, several adult specimens being isolated until the eggs were laid on the under surface of stones and these eggs were then kept in aquaria and examined every day. In this way a series of drawings was made from the day the egg was laid up to a few days after hatching. Gobius Ruthensparri were also isolated and eggs were laid in an empty oyster shell. These were also reared and drawings made up to the time of hatching. It is hoped later to do the same with the other species.

The young gobies from the Young Fish Trawl occurred from May to October and were most common in the tow-nets from July to September, the commonest size being from about 10 to $15 \mathrm{~mm}$. Young Aphya occurred in the Young Fish Trawl in 1913 in July to September measuring from about 10 to $20 \mathrm{~mm}$., but only older specimens occurred in the tow-nets, and these only very rarely. Most of the Crystallogobius captured in the Young Fish Trawl were of fairly large size.

Of the young of the Gobius species from deeper water, G. elongatus is 
undoubtedly the commonest, $G$. Jeffreysii coming next. At times in deeper water, but more commonly nearer the shore the young of $G$. pictus is fairly abundant. The commonest young gobies caught in the townets are Gobius Ruthensparri, paganellus and microps, although G. minutus is quite as common in the adult stage and abounds in the Sound from the Cattewater to the Breakwater and along the coast outside the Breakwater, notably in Cawsand Bay.

\section{GOBIUS MINUTUS Pallas.}

Plate I, Fig. 1.

There seems to be enough evidence to show that Gobius minutus and Gobius microps are distinct species. Boulenger (1911) has separated them clearly by their scales and fin formulæ as well as by their shape and colour, and Fage (1914) by their sensory papillæ, which are extremely different in their arrangement in the two. Petersen (1917) has described the two species together as Gobius minutus whilst recognising that there are two forms, one with 33 vertebræ and one with 31 . These two are recognisable at Plymouth and are quite distinct and easily separated both in the young and adult. Gobius microps also lives much higher. up the estuaries than Gobius minutus although the young occur in the Sound.

Gobius minutus is very common in the Sound not far from land. It was not taken in the Young Fish Trawl in 1913 and 1914, the species corresponding to it being $G$. elongatus which seems to be the deep sea form of G. minutus of Holt and Byrne (1901) and the form norregicus of Collett (1902). Young Gobius minutus were taken by the tow-nets in the Sound and we also have specimens from Cawsand Bay and the Tamar. It is one of the commonest gobies inside the Breakwater and at the mouths of the estuaries and also near the coast by the open sea, e.g. Whitsand Bay. Eggs of what are almost certainly this species are frequently dredged in the Sound inside the Breakwater.

The pigment in the live young specimens is chiefly black, with a diffuse yellow tinge especially dorsally in the region of the largest tail chromatophores, and besides yellow there is a small amount of reddish especially near the air bladder. The body is extremely clear and transparent, the eyes blue with yellow glints. All but the black disappears on preservation. The smallest of the specimens measures $12 \mathrm{~mm}$. in length. In these there is little pigment. The head has one chromatophore at the angle of the jaw and one star-like chromatophore in the region of the otoliths, but no large chromatophore under the ear capsule as there is present in microps. It is probable, however, that this exists in the very 
PLATE I.
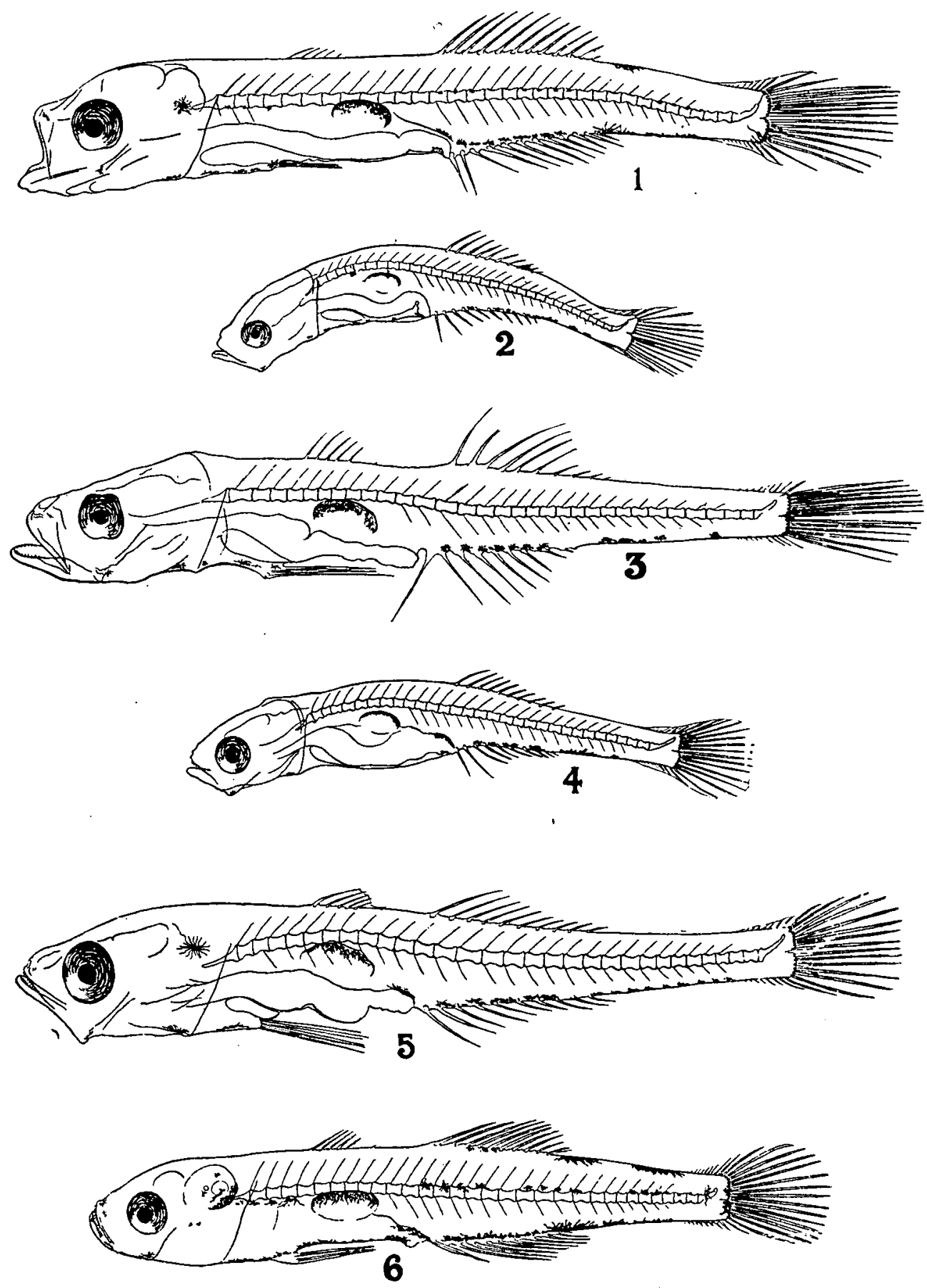

M. V.L. 
young stages and disappears as it does in $G$. Ruthensparri, for young hatched out of eggs which were almost certainly Gobius minutus possessed this chromatophore. There may be a small chromatophore in the nose region. Usually there is no dorsal pigment at this stage although there may be one chromatophore behind the second dorsal fin. Later on this is always present. There are usually chromatophores from the throat to the base of the pelvic fin, but hardly any pigment below the intestine until just in front of the anus, where there is one chromatophore. There is the usual pigment on the dorsal surface of the air bladder. From above the anus along the base of the anal fin as far as about the level of the second vertebra from the tail end is a series of chromatophores, interrupted at about the level of the 11th vertebra from the tail end for a space equal to about two or three vertebræ. Just behind this is a specially ramified chromatophore, which lies immediately opposite the single dorsal chromatophore when that is present. Two or three streaks of pigment occur on the ventral half of the caudal fin. Indication of three groups of pigment spots along the region of the vertebræ may occur at this stage, and soon afterwards these are always present. At $15 \mathrm{~mm}$. there may be, and usually is, a chromatophore in the front of the lower jaw, and the dorsal pigment may have increased to several chromatophores behind and in the region of the second dorsal fin, but usually, not near the first dorsal even at $16 \mathrm{~mm}$. At $18 \mathrm{~mm}$, in the largest specimen, taken at Cawsand Bay, the pigment has increased so that there are several small chromatophores on the upper and lower jaw and in the ear region, and dorsally on the top of the head and in front of the first dorsal fin. A chromatophore is now present at the base of the 5th ray of the first dorsal and at the base of several of the rays in the second dorsal. The three patches of pigment are more distinct, and there is now one in front of the air bladder and one at the base of the tail fin. The pigmentation at this stage approaches that of microps at $10 \mathrm{~mm}$., although there are distinct differences, notably the absence in minutus of the large chromatophore under the ear capsule, besides the much more intense pigment of microps.

The vertebræ number 33 in 15 out of 16 counted, the 16 th having 34 . In an adult from Whitsand Bay there were also 33, one specimen from

Explanation of Plate I. (Pectoral fins omitted.)

Fra. 1.-Gobius minutus, length $12 \mathrm{~mm}$. From tow-nets, Plymouth Sound, August 13, '18. Fia. 2.-Gobius elongatus, length ca. $7 \mathrm{~mm}$. From 2 miles beyond Prawle Point, Young Fish Trawl, July 2 ,' 14.

Fia. 3.-Gobius elongatus, length $12.2 \mathrm{~mm}$. Same locality, July 2, '14.

Fra. 4.-Gobius pictus, length $7.5 \mathrm{~mm}$. From off Looe, Young Fish Trawl, August 13, '13. Fia. 5.-Gobius pictus, length $12 \mathrm{~mm}$. Same locality, August 13 , '13.

Fia. 6.-Gobius microps from fresh specimen, length $10 \mathrm{~mm}$. From tow-nets inside the Breakwater, September 6, 'is. 
Ireland had 32. 33 may be regarded as the typical number which agrees with Petersen's more open water form of minutus (1917). The fins are D II 11-12, A 11-12, usually 12 in both dorsal and anal, sometimes 11 in one and 12 in the other. The eye is larger than in microps of the same size. Thus at $12 \mathrm{~mm}$. it measures $0.7 \mathrm{~mm}$. across which is about the same as in microps of $14 \mathrm{~mm}$. At $15 \mathrm{~mm}$. it measures $0.8 \mathrm{~mm}$. across.

At $12 \mathrm{~mm}$. the permanent rays of the pectoral fin are not completely developed, the pelvics reaching not quite to the level of the centre of the air bladder. At $13 \mathrm{~mm}$. they may reach to the end of the air bladder and at $14 \mathrm{~mm}$. to just beyond it. At $15 \mathrm{~mm}$. the pectoral rays are developed and the pelvics reach nearly to the anus, which is the adult position.

Gobius minutus may thus be distinguished from microps in its young stages by its less intense pigmentation, notably the absence of a large chromatophore under the ear capsule (with the probable exception of the newly hatched stage), by the larger number of vertebræ and fin rays, less rapid development of the pelvic fins and by the larger eye. In the adults and in the young stages of about $20 \mathrm{~mm}$. or less, the sensory papillæ show a totally different arrangement in the two species.

\section{GOBIUS ELONGATUS CANESTRINI}

\section{Plate I, Figs 2 and 3.}

The first mention of this species is by Canestrini (1862) from the Gulf of Genoa. Fage (1917) describes it as differing from the typical Gobius minutus by its slenderer build, absence of scales on the neck and throat and the persistence of certain larval characters, the chief being the arrangement of the sensory papillæ, which is nearer to the young Gobius minutus than it is to the adult. It apparently takes the place of $G$. minutus in the Mediterranean. This species seems to take the place of $G$. minutus also in the deeper waters round about Plymouth, and it is apparently the more open water form of Gobius minutus of Holt and Byrne (1901) and the Gobius minutus form norvegicus of Collett (1902). Through the kindness of Mr. Holt I have been able to examine some of his specimens from Ireland, which agree with the characters given for $G$. elongatus, especially with regard to the sensory papillæ and pigmentation of the adult, which in the male particularly, is inclined to be in bars along the body. The fin formula agrees with Canestrini, D VI 9-10, A 9-10. A few of the Irish specimens have 11 rays in both dorsal and anal. Only a few adult specimens are available from the Plymouth waters, but these agree with the characters given above, having less fin rays than Gobius minutus proper, streaky pigmentation and sensory papillæ as described by Fage. The papillæ are in all the 
specimens much less strongly developed than in minutus and much more difficult to see, especially in half-grown specimens which are only very slightly pigmented.

Young specimens are very common in the Young Fish Trawl both in 1913 and 1914, always from deeper water and often with the young of Gobius Jeffreysii. They range from quite small specimens of about $5 \mathrm{~mm}$. long to older forms up to about $18 \mathrm{~mm}$. The latter show to a certain extent the sensory papillæ characteristic of $G$. elongatus and differ somewhat from those in the young minutus, but they are still in the post-larval stage and very little pigmented.

The typical number of vertebræ is 32 . Fins D VI 9-10, A 9-10 (rarely 11 in both). Rarely there are 7 rays in the first dorsal fin.

This is by far the commonest young Gobius from the Young Fish Trawl from 23 to 36 fathoms, from beyond the Eddystone, Rame Head, off Prawle Point and Start Point and beyond Looe Island. It is often accompanied by the young of Gobius Jeffreysii, occasionally by the young of Gobius niger, but is never found with Gobius minutus, microps nor Ruthensparri. Aphya and Crystallogobius occasionally occur with it and Gobius pictus of a fairly large size, although not actually caught with it occurred sometimes in the same localities.

The youngest stage found in the Young Fish Trawl measures $5 \mathrm{~mm}$. and the oldest $18 \mathrm{~mm}$. The young specimens (preserved only, as no live material was examined which contained this species) up to about $10 \mathrm{~mm}$. and more have very little pigment, none at all in or on the head except a touch of black at the angle of the jaw, a few chromatophores on the throat and sometimes below the alimentary canal, the usual pigment on the air bladder and a row of ventral chromatophores usually beginning well behind the anus and reaching to nearly the end of the tail. These ventral chromatophores are interrupted at about the level of the 10th or 11th vertebra for a space equal to about three or four vertebræ. The first chromatophore behind the space is usually but not always ramified. Later on, sometimes at $10 \mathrm{~mm}$., sometimes not till after $14 \mathrm{~mm}$., there is a chromatophore in the auditory region in the same position as it is in Gobius minutus. A chromatophore behind and above the anus is absent in nearly all the specimens, occasionally being indicated by a minute black spot, rarely being fully developed. In older specimens, after about $16 \mathrm{~mm}$., chromatophores appear at intervals along the vertebral column, and at about $18 \mathrm{~mm}$. speckles appear externally with regular dark spots.

The eye is small, conspicuously smaller than in minutus and pictus, measuring at $7 \mathrm{~mm} .0 .32 \mathrm{~mm}$. across, and at $12 \mathrm{~mm} .0 .64 \mathrm{~mm}$. across, although an occasional abnormal specimen may have a larger eye.

The body is long and thin. At a length of $7 \mathrm{~mm}$. the unpaired fins, 
except the first dorsal, are developed and have the complete number of fin rays, usually 10 in both dorsal and anal, sometimes 9 , rarely 11 (11 have never been seen in the Plymouth specimens). At $12 \mathrm{~mm}$. the first dorsal is formed and has longer rays than in $G$. minutus of the same length. The pelvics at this stage reach to the end of the air bladder or past it. All the fins in the young have a somewhat straggling appearance and the fin membranes are easily torn.

The number of vertebræ may reach 33 and probably may go down to as low as 30 , but 32 is the typical number. A specimen having 33 vertebræ can be distinguished from minutus by the smaller number of fin rays in the second dorsal and anal fins and the smaller eye. If, as rarely happens, a specimen has 31 vertebræ, which is the typical number for microps, it can be distinguished by the very different pigmentation, but it is hardly likely to be confused with that species as it always inhabits much deeper, water than microps and is never found inshore. It is with Gobius pictus that it is most likely to be confounded in the young stages, for if they occurred together it seems almost impossible to distinguish the two if not quite typical, for although typically $G$. elongatus has 32 vertebræ, a very small eye and no chromatophore behind and above the anus, specimens sometimes occur with one or two of the following characters-31 or 30 vertebræ, larger eye, or a chromatophore above and behind the anus as in $G$. pictus, and G. pictus although apparently never having more than 30 vertebræ and always possessing the typical chromatophore above and behind the anus may rarely have a much smaller eye.

It is probable, however, that whilst Gobius elongatus occurs always in fairly deep water Gobius pictus in the young stages lives nearer the shore, although when older, at 23 to $30 \mathrm{~mm}$., and when adult the latter also occurs in deeper water. The variable specimens which occur among the young $G$. elongatus are thus more likely to be variations in that species than isolated specimens of Gobius pictus.

Gobius elongatus although so little pigmented is easily distinguished from Aphya by the number of vertebræ and fin rays, and especially by the development of the paired fins, also by the chromatophore at the angle of the lower jaw, which is absent in Aphya.

\section{GOBIUS PICTUS MaLm.}

Plate I, Figs. 4 and 5. Plate II, Fig. 1.

Gobius pictus has a wide range of distribution, as it occurs in the Sound chiefly near the shore, more rarely right out as far as Rame Head. It is often taken with Gobius minutus and Ruthensparri, and the young occurred in the Young Fish Trawl in 1913 in August to October. Those from off Rame Head in October were much older than the others and 


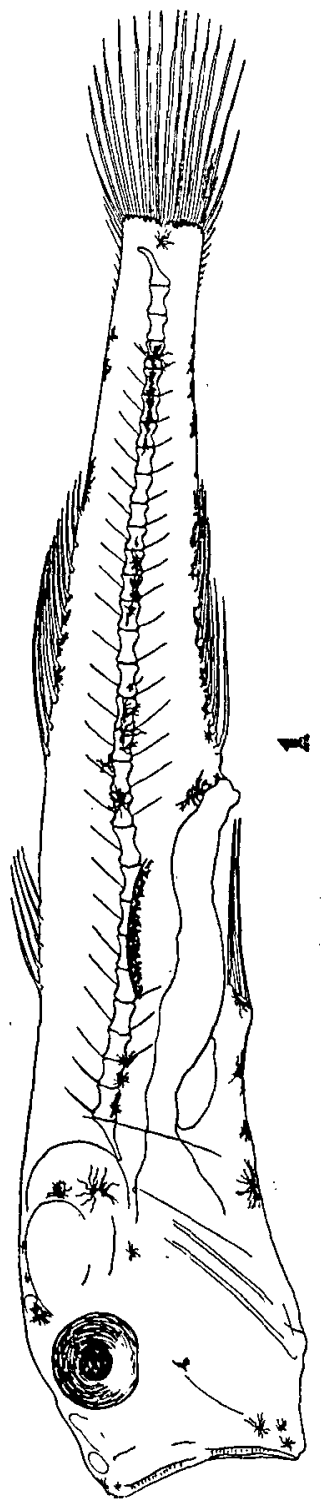

PLATE II.

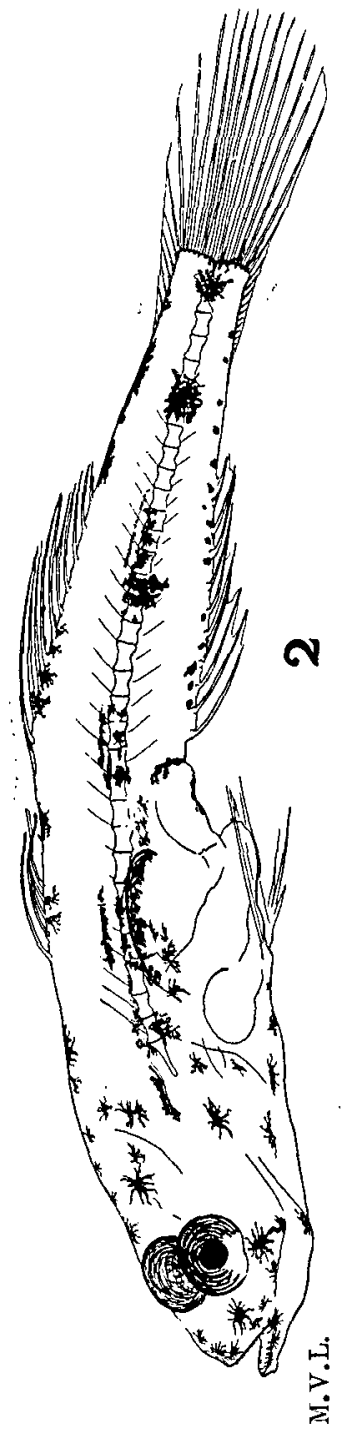

Explanation of Plate II. (Pectoral fins omitted.)

Fro. 1.-Gobius pictus, length $14 \mathrm{~mm}$. From tow-nets inside the Breakwater, August, ' 18.

FIG. 2.-Gobius microps, length ca. $14 \mathrm{~mm}$. From Young Fish Trawl off Penlee, September 4, '18. 
measured 23 to $30 \mathrm{~mm}$. They were much less pigmented than those of the same size from the Cattewater although the sensory papillæ and ther features showed them to be this species. The younger stages from near the shore are also more pigmented especially about the head.

The smallest captured were by the Young Fish Trawl off Looe, August, 1913 , the depth being rather more than 10 fathoms. They were accompanied by the young of Aphya pellucida. In the haul were over a hundred specimens of Gobius pictus ranging from about $5 \mathrm{~mm}$. to $15 \mathrm{~mm}$. in length. Others of 15 to $17 \mathrm{~mm}$. were from Cawsand Bay, Bigbury Bay and inside the Breakwater, the latter being the only specimen caught in the tow-nets. The only specimens from deep water identified with certainty were from beyond Rame Head in October, 1913, 147 in one haul, 15 in another. These measured from 23 to $33 \mathrm{~mm}$. It is possible that the fish come near the shore to breed and then go out again, as no young stages from below $23 \mathrm{~mm}$. have been identified from the deeper water. It is possible, however, that a few specimens among the young Gobius elongatus from deeper water may belong to this species, although it seems more likely that they are variations of $G$. elongatus (see above).

The younger stages of $G$. pictus are very much like those of $G$. elongatus, but the usual number of vertebræ in pictus is 30 instead of 32 . The fin formula is the same for both species, D VI 9-10, A 9-10. There may be 29 vertebræ in pictus which is the case in one of those figured (Fig. 1, Plate II). Holt and Byrne (1901) give 28 vertebræ for this species, and Petersen (1917) gives 30 and 29 for those from Norway. From the present specimens counted it seems that 30 is the more usual number, 29 rather exceptional.

The only live specimen, measuring $14 \mathrm{~mm}$., from inside the Breakwater had a good deal of yellow about it with the black and a little red, but as it was preserved at once details were unfortunately. not noted. The smallest specimens of $5 \mathrm{~mm}$. in length have the usual row of ventral chromatophores from anus to tail, slightly interrupted at the level of the 11th or 12th vertebra from the tail, but the interruption is nearly always slighter than it is in G. elongatus and minutus : there are large chromatophores at the throat and smaller chromatophores more or less apparent below the alimentary canal. A fairly large chromatophore is always present behind and above the anus, whilst its occurrence is exceptional in $G$. elongatus. The eye is larger than it is usually in G. elongatus. The fin rays are beginning to form in those of $5 \mathrm{~mm}$, and they are fully formed at $7 \mathrm{~mm}$. At $12 \mathrm{~mm}$. and sometimes earlier a large ramifying chromatophore is present in the auditory region, and at $14 \mathrm{~mm}$. there may be a few more near it, and also chromatophores at the base of some of the rays in the second dorsal fin and behind it, 
and dark patches in the region of the vertebral column. At 12 and $14 \mathrm{~mm}$. the eye is distinctly larger than it is in G. elongatus of the same length, measuring about $0.72 \mathrm{~mm}$. across at $12 \mathrm{~mm}$., and $0.86 \mathrm{~mm}$. across at $14 \mathrm{~mm}$., whilst that of $G$. elongatus at $12 \mathrm{~mm}$. measures only about $0.56 \mathrm{~mm}$. across. The difference in the size of the eye is particularly noticeable at this stage. The specimen from inside the Breakwater is more pigmented than those from off Looe, approximating more in pigmentation to G. microps, but is easily distinguished from that species by the absence of the large streak-like chromatophore beneath the auditory capsule, the fewer vertebræ and the larger eye, besides being still much less intensely pigmented than microps. The pelvic fins are absent at $7 \mathrm{~mm}$., at $12 \mathrm{~mm}$. they reach to slightly beyond the level of the hind end of the air bladder, at $14 \mathrm{~mm}$. they reach nearly to the anus.

The older specimens from beyond Rame Head are much more developed and are practically like the adult. In those of $23 \mathrm{~mm}$. the eyes are on the dorsal surface, the scales are present, the adult fins developed and the characteristic arrangement of the sensory papillæ can be recognised. However, in comparing specimens from the mouth of the Cattewater they are seen to be much paler than these, so that they cannot be recognised by pigment alone as one can recognise the adults. The pale colour may be due to preservation, but this is not very likely to be the case as adults keep their colour well in the same preservative.

The few very young specimens with 30 vertebræ from deeper water, that occurred with $G$. elongatus, probably belong to that species although it is exceedingly difficult to distinguish them from pictus with any certainty. Some agree with pictus in number of vertebræ and chromatophore above the anus, but the eye is more like elongatus, others are without the chromatophore, but have 30 vertebræ. The two species at this stage $(7-10 \mathrm{~mm}$.) can only be separated with difficulty, and the fact that one or two abnormal specimens occur with a number of $G$. elongatus in the usual habitat of the latter renders it more probable that we are dealing with a variety of elongatus than with G. pictus.

That the above-described specimens are really the young of Gobius pictus there can be little doubt, for the only other species with the same number of vertebræ and fin rays is Gobius Jeffreysii, which inhabits deep water and apparently never comes inshore, although G. pictus may occur in deeper water as well as near the shore. The young of what must be regarded as $G$. Jeffreysii were taken frequently in the deeper water, but never near shore, and finally the older specimens of G. pictus at $23 \mathrm{~mm}$., which from their sensory papillæ, vertebræ and fins show them to be undoubtedly this species, agree very well with the younger forms. 


\section{GOBIUS MICROPS KRÖYER.}

\section{Plate I, Fig. 6. Plate II, Fig. 2.}

Gobius microps is definitely recognised as a species by Boulenger (1911), and Fage (1914) shows that it can be distinguished from pictus to which it is closely related, by the arrangement of the sensory papillæ. The number of vertebræ is typically 31, fin rays D VI 9-10, A 9-10. This species lives chiefly in estuaries and occurs as high up as Chelson Meadow by the Laira. In the Sound the young are caught in the townets, and with the Young Fish Trawl specimens were taken by Clark in 1913 from Jennycliff Bay, and in 1914 from Cawsand Bay and one off Penlee Point.

Specimens from $5.5 \mathrm{~mm}$. to $12 \mathrm{~mm}$. in length occurred from various parts of the Sound as far out as the Knap Buoy, but usually within the Breakwater. They were commonest in July, and a live specimen of $10 \mathrm{~mm}$. was taken in the tow-nets on July 24th, 1918, and kept alive till December when it measured $16 \mathrm{~mm}$. and was very clearly a Gobius microps. The pigment when alive was very bright. The intensely black chromatophores were mixed with a bright yellow with a little red, the yellow spreading on to the sides and dorsally on the tail. Those of 16 to $18 \mathrm{~mm}$. showed many black speckles both internally and externally.

The young are long and narrow with a small eye from $0.30 \mathrm{~mm}$. across at $14 \mathrm{~mm}$. The pigment is very conspicuous and agrees with Petersen's figures of Gobius minutus (including microps) at 7 to $14 \mathrm{~mm}$., all three of which are apparently drawings of microps (1917). From the smallest to the largest there is an almost continuous row of black chromatophores ventrally from anus to tail, which specially ramify just behind the anal fin, and are placed opposite one or two dorsal chromatophores which also ramify and occur immediately behind the second dorsal fin. When the ventral chromatophores are contracted there is a slight interruption at about the level of the 12th vertebra from the tail. Beneath the auditory capsule is a large chromatophore, and in the region of the larger otolith (there is one very large and one very small) is a smaller starshaped chromatophore. At the angle of the jaw is a conspicuous chromatophore and a series from the throat to the anus, sometimes leaving a gap in the region below the air bladder. This pigmentation occurs in all from $5.5 \mathrm{~mm}$. to $14 \mathrm{~mm}$. Usually also in those from $7 \mathrm{~mm}$. onwards there are pigment spots on the lower jaw and above the eye, often also in front of the eye. At $9 \mathrm{~mm}$. two more spots may appear in the region of the auditory capsule, but these may not come until later. At $11 \mathrm{~mm}$. there are a good many more pigment spots on the head and at $14 \mathrm{~mm}$. still more. With the increase of pigment on the head comes pigment at the 
base of the rays of the second dorsal fin, pigment above and below the vertebræ forming three elongated dark patches, and more pigment at the base of the caudal fin. Later on come patches of pigment on the outside corresponding to pigment along the vertebræ. In the specimen of $14 \mathrm{~mm}$. the pigment is connected with the rays of the first dorsal fin. In all there is much pigment on the dorsal surface of the air bladder.

In 29 specimens, all except one had 31 vertebræ, one having 30 only. In all of these the number of fin rays in both second dorsal and anal fins is 10. The pectoral fin rays are not developed until about $10 \mathrm{~mm}$. and then only feebly. The pelvics at $8.5 \mathrm{~mm}$. reach to beyond the level of the centre of the air bladder, at $11 \mathrm{~mm}$. they reach nearly to the anus, but apparently even in the larger specimens never quite reach it. A specimen of $18 \mathrm{~mm}$. from Chelson Meadow has a speckly appearance, very much pigmented dorsally, but the large spots and patches not definitely marked. Eye $1 \mathrm{~mm}$. across. A specimen of $25 \mathrm{~mm}$. from the same locality has all the appearance of the adult, but-the sensory papillæ under the eye have not reached the full number. From Gobius pictus, which is the species nearest to it, the young of microps may be distinguished by the pigment, smaller eye and larger number of vertebræ. The head in pictus is longer than that of microps, which can be easily seen in the older specimens of about $23 \mathrm{~mm}$. and over. Gobius pictus also is sometimes found much further out to sea than microps, and although it is captured at the mouths of estuaries with minutus it apparently never penetrates up them as microps does. The distinguishing character of minutus and microps will be found under the description of Gobius minutus (p. 55).

\section{GOBIUS JEFFREYSII ETHR.}

Plate III, Figs. 1 and 2.

Gobius Jeffreysii is a deep water goby. Holt and Byrne (1901) state that its habitat is from 19 to 180 fathoms. The adult is common at the mouth of the Sound beyond the Mewstone and on the Eddystone grounds, but the young stages have not as yet been described.

Among the young fish caught in the Young Fish Trawl in 1913 and 1914 from the deeper water, chiefly from beyond Rame Head and the Eddystone from May to August, were some very distinct young stages of a much pigmented goby with.its paired fins developed very early, long fin rays and eyes on the top of the head at a length of $12 \mathrm{~mm}$. or less. In all those counted (25) there were 30 vertebræ, fin formula D VI 9-10, A 9-10. A few adult $G$. Jeffreysii from the same localities showed 30 vertebræ and the same fin formula as above. The only other 
PLATE III.
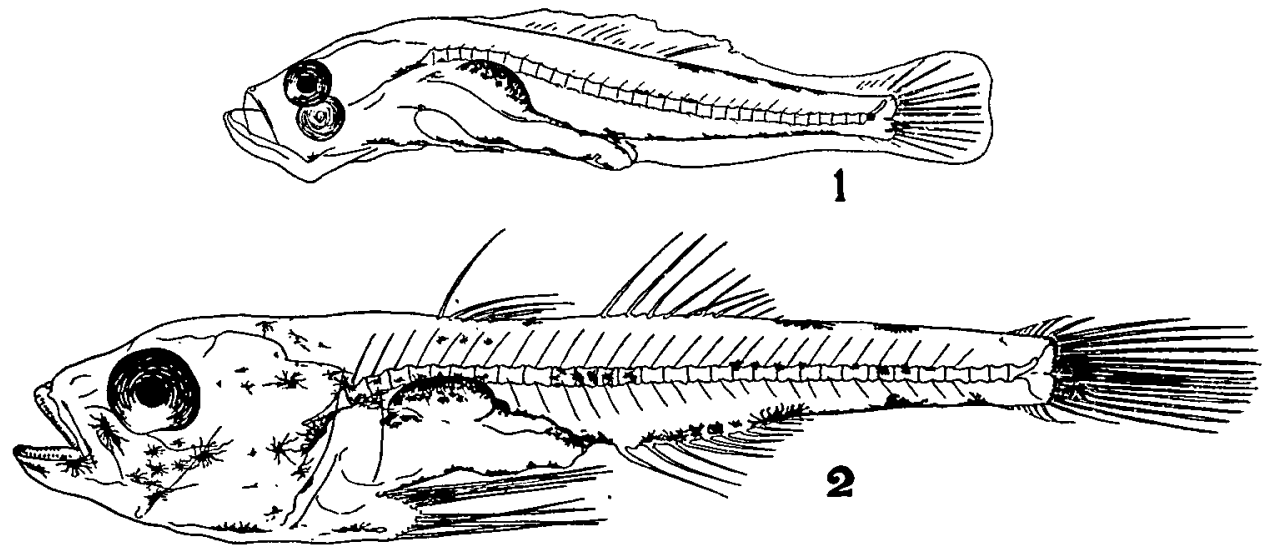

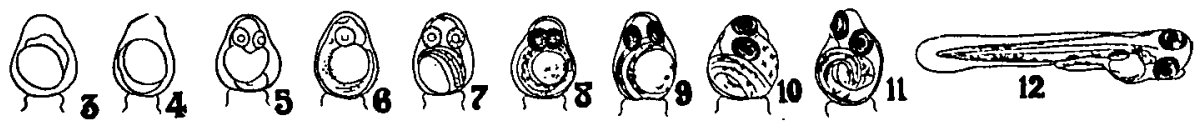
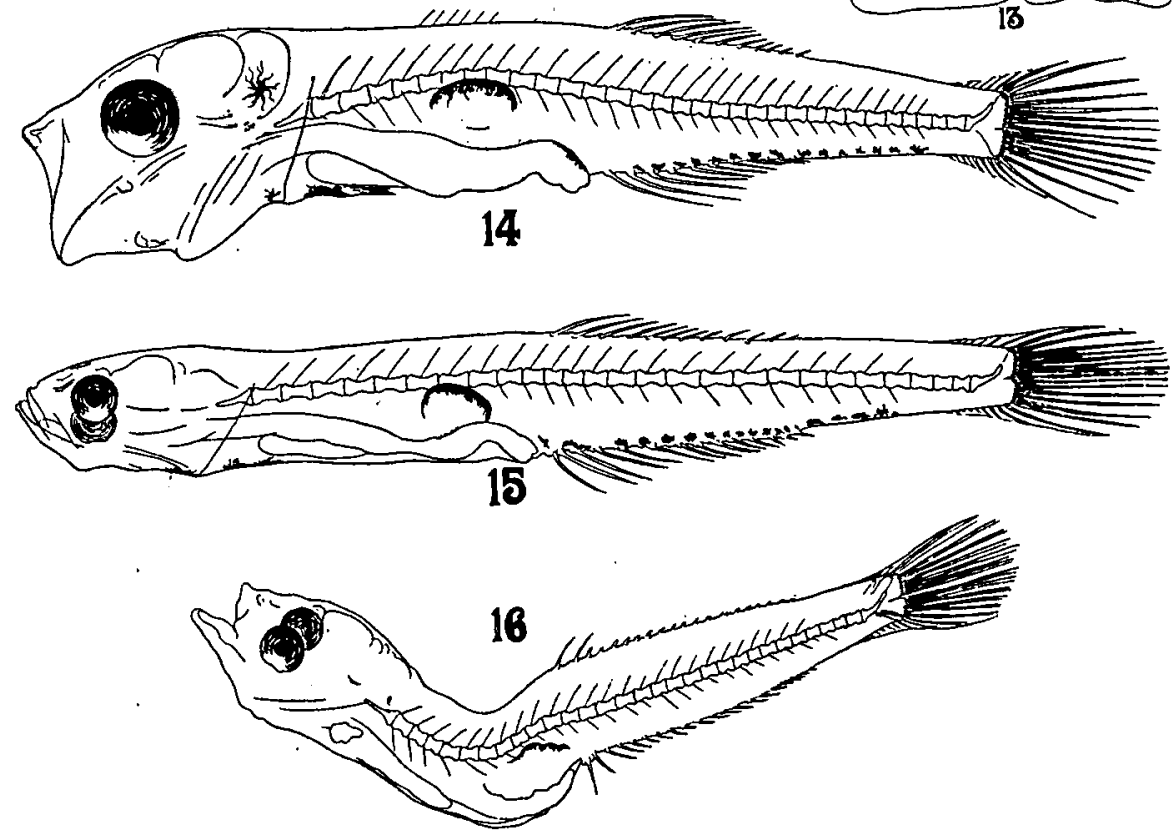

M.V.L. 
species of Gobius that has typically 30 vertebræ and the same fin formula is Gobius pictus, the young of which although found sometimes as far out as G. Jeffreysii occurs more commonly much nearer the shore, and can easily be distinguished from it by its different pigmentation, shorte: fin rays and by its remaining in the post-larval condition until it reaches a much greater length.

The arrangement of the sensory papillæ in the adult Gobius Jeffreysii was examined, although as the specimens were not in good condition the examination was necessarily incomplete. Enough was seen, however, to show that it approximates in arrangement to Gobius affinis (Sanzo, 1910. T. 9, Fig. 9), Fig. 3.

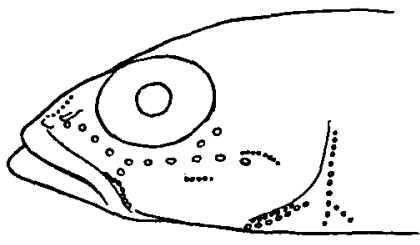

A

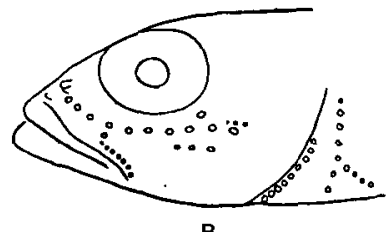

B

Fia. 3.-Diagram showing arrangement of the sensory papilla on the head of Gobius Jeffreysii. A. adult, B. young form.

In the young above mentioned, the larger specimens measuring 15 to $17 \mathrm{~mm}$. had an arrangement of the sensory papillæ which showed the same type as that of Jeffreysii although not quite the same as the adult. A specimen of $17 \mathrm{~mm}$. had large scales beginning to be formed from the region behind the pectoral fin along the body. It seems therefore that one is safe in attributing this post-larval form to Gobius Jeffreysii. It always occurs fairly far out, and in the present material has not been taken at a less depth than 20 fathoms. It is. generally accompanied by the young of Gobius elongatus, which with occasional specimens of Gobius niger is the only other Gobius commonly found in such deep water.

\section{Explanation of Plate III. (Pectoral fins omitted.)}

Fia. 1.-Gobius Jeffreysii, length ca. 7. mm. From Young Fish Trawl, north of Eddy. stone, June 25 , '14.

Fra. 2.-Gobius Jefreysii, length $12 \mathrm{~mm}$. From Young Fish Trawl, N.E. Prawle Point, July 2 , '14.

FIas. 3-12,-Eggs and newly hatched young of Gobius Ruthensparri laid and hatched

- in the Laboratory, drawn every day from July 30th (probably the second day) to August 7 th, the day of hatching. Fig. 3, egg $0.70 \mathrm{~mm}$. long. Others the same scale. Fia. 12, 2.6 mm. long.

Frc. 13.-Gobius Ruthensparri, $3.1 \mathrm{~mm}$. long, hatched in a tank in the Laboratory, probably 4 or 5 days old.

Fra. 14.-Gobius Ruthensparri, length $11 \mathrm{~mm}$. From near Panther Buoy, Plymouth Sound, July 5 , '18.

Fia. 15.-Aphya pellucida, length $11 \mathrm{~mm}$. Young Fish Trawl off Bell Buoy, Looe, August 13, ' 13.

Fic. 16.-Crystallogobius Nilssoni, length ca. $8 \mathrm{~mm}$. Young Fish Trawl, 4 miles beyond Rame Head, Attgust 12, '14. 
These young forms are common in the collections from the Young Fish Trawl and are the most striking of all the post-larval gobies, pigment at a very early stage being well developed and the fin rays very conspicuous. The most usual size is from 12 to $14 \mathrm{~mm}$., and in these the eyes already almost meet on the top of the head. They are easily recognised from the other post-larval gobies by the position of the eyes (Gobius niger being the only species having them on the top so early) and three pigment spots, one behind the 6th ray of the first dorsal fin and spreading on to it, and two behind the second dorsal. The thick build, large eye and long fin rays are also characteristic.

The smallest specimens measure $7 \mathrm{~mm}$. and are from beyond the Eddystone, the depth being over 30 fathoms. These still retain the larval fin although rays are developed in the tail and are beginning to form dorsally and ventrally. Vertebræ 30 , pigmentation very characteristic, chromatophores being present from behind the air bladder to the anus in a continuous line which persists in all the stages. There is a chromatophore at the angle of the jaw and a large chromatophore under the auditory capsule as it is in microps. From the throat to the anus is an uninterrupted series of chromatophores which also run from the anus to near the end of the tail. Dorsally there are three or four chromatophores opposite the ventral tail row and behind the developing second dorsal fin. In the region of the vertebræ are groups of small chromatophores. The eyes at this stage are not very large, about $0.48 \mathrm{~mm}$. across. The pectoral and pelvic fins are very feebly developed, the pelvics reaching to about the middle of the air bladder which is heavily pigmented. At $10 \mathrm{~mm}$. the fins are well developed and the characteristic post-larval pigmentation is present. At $12 \mathrm{~mm}$. the form is peculiarly thick and heavy, eye large, $1 \mathrm{~mm}$. across, fin rays long, the rays of the first dorsal reaching nearly to the beginning of the second dorsal, pectorals and pelvics well developed, the pelvics extending behind the anus, head heavily pigmented in front of and below the eye and in the auditory region, air bladder very far forward beginning near the second vertebra, three chromatophores dorsally, the first below and upon the 6th ray of the first dorsal fin, the other two large and ramified behind the second dorsal corresponding to the two largest ventral chromatophores, vertebral pigment in four patches along the body.

At 15 to $17 \mathrm{~mm}$. there are four dark patches externally corresponding to the vertebral pigment and showing up conspicuously as intense brownish black spots. The rest of the pigment is much the same, but scales are beginning to form in the largest specimen $(17 \mathrm{~mm}$.), which are large and the sensory papillæ approximate in arrangement to the adult Gobius Jeffreysii. 


\section{GOBIUS RUTHENSPARRI EUPHRAS.}

Plate III, Figs. 3-14.

Gobius Ruthensparri occurs commonly in the Sound, often swimming among the Zostera. In the adult stage it lives near the surface, and consequently its eyes are permanently far apart on the sides of the head instead of close together on the top like the bottom species. The young are the commonest gobies in the tow-nets from the mouths of the estuaries to beyond the Panther Buoy, and by the Young Fish Trawl it was sometimes taken in the Sound, but never in the deeper water outside.

Several adults caught at the mouth of the Cattewater were isolated in a tank and one deposited eggs on the inside of an empty oyster shell on July 30th. The eggs which were distinctly marked with small groups of fine striations over the surface had probably been laid a day when found. They measured about $0.7 \mathrm{~mm}$. in height and are much like those described by Petersen (1892), but vary much in shape, as can be seen from the drawings taken every day until the young were hatched on August 7 th. They thus only take about ten days to hatch and measure $2.6 \mathrm{~mm}$. when newly hatched. On July 31st eyes and lenses were distinct and pigment appeared on August 1st which rapidly spread on to the eyes and along the tail, the pupils being black on August 4th, and the pigment concentrated especially on the tail. The newly hatched young has a large yolk sac, a conspicuous dark chromatophore under the auditory capsule and chromatophores ventrally from the throat to the end of the tail. The colouring in the live specimens is yellow and black with no red at this stage, the black being very intense. It is to be noted that in this species the chromatophore under the auditory capsule disappears very soon, whereas in G. microps it is present in all the post-larval stages.

The post-larval stages are commonest in July and August. All the young stages have been well described by Petersen (1917) from Denmark, where with $G$. niger, microps and minutus they are abundant.

The smallest specimen from the tow-nets measures $5 \mathrm{~mm}$. and agrees with Petersen's description, as also do all the other stages. A live specimen measuring $10 \mathrm{~mm}$. was captured on July 7 th and kept alive in a small aquarium. On December 5th it measured $25 \mathrm{~mm}$. and had all the adult characters. At about $10 \mathrm{~mm}$. and after, the live specimens have a good deal of a pinkish red pigment at the tail end, along the ventral surface and internally in a row of spots along the vertebral column. There is also yellow pigment mixed with the black. Up to about $10 \mathrm{~mm}$. there is little pigment, the continuous row of black 
PLATE IV.
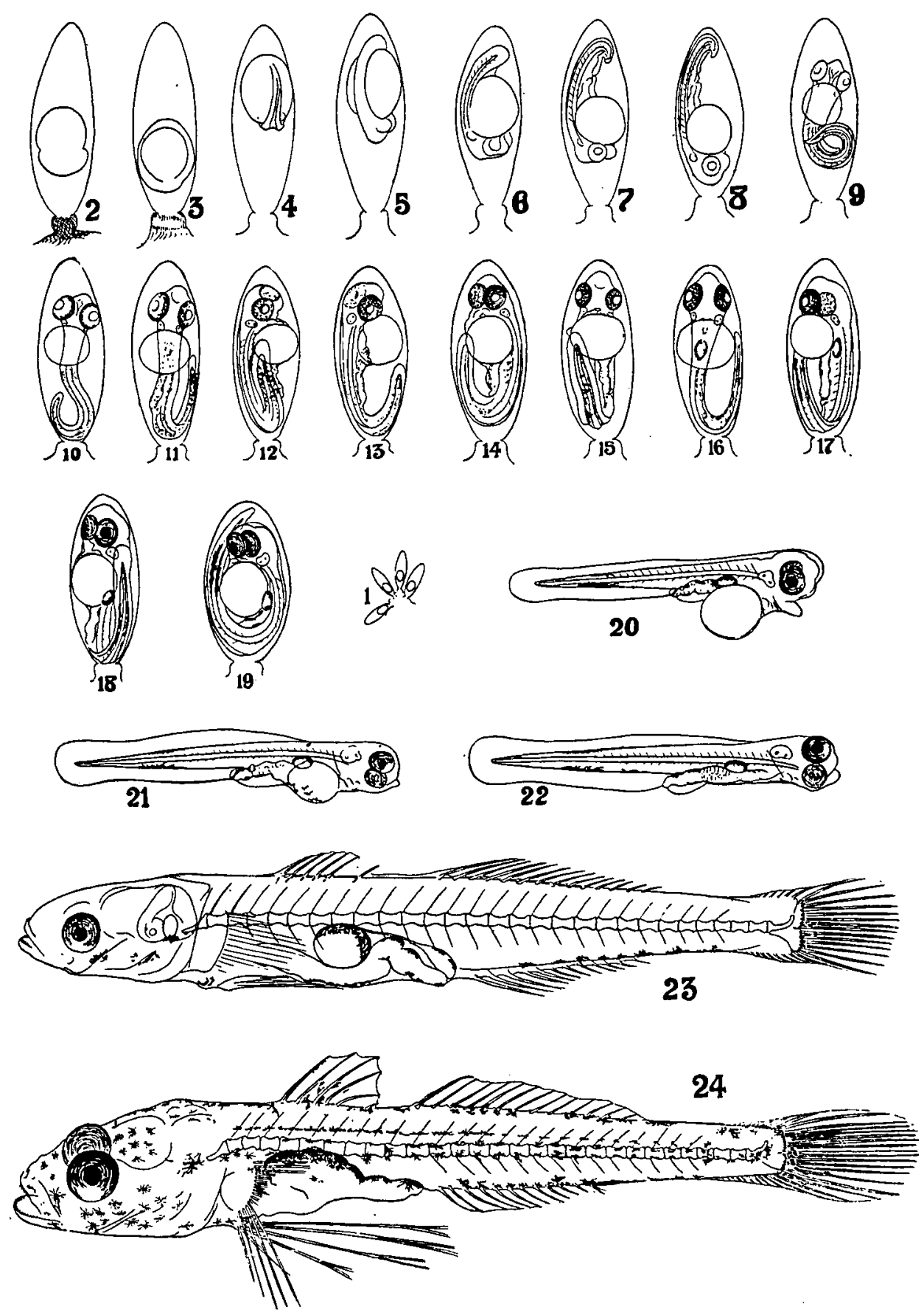

M. V.L. 
chromatophores from anus to tail being characteristic, and these are very seldom ramified. At about 8 or $9 \mathrm{~mm}$. a large chromatophore appears in the auditory region, and there is pigment at the angle of the jaw and on the throat, but not along the ventral surface of the alimentary canal. Behind and above the anus there is the usual large chromatophore which is absent only in Gobius elongatus amongst all the young gobies here described. The pelvic fin has not appeared at $9 \mathrm{~mm}$., and at $11 \mathrm{~mm}$. it does not reach as far as the front of the air bladder. At $11 \mathrm{~mm}$. all the rays of the first dorsal fin are present having the arrangement shown in Fig. 2B. The fin formula is D VII 11, A 11, the number of vertebræ is 32 in all those counted (over 30 ). The eye is large, $0.76 \mathrm{~mm}$. across in a specimen $11 \mathrm{~mm}$. long. It is thus larger than G. elongatus and nearly the same size as G. pictus. After $10 \mathrm{~mm}$. the black pigment (the red only showing in live specimens) is present in a continuous series of spots in the region of the vertebral column, and after $12 \mathrm{~mm}$. there is much more pigment altogether, the body having a speckled appearance and the paired fins rapidly developing.

The only species which also has 32 vertebræ is Gobius elongatus, but the habitat being quite different they are not likely to be confused. Distinguishing characters are the continuous ventral series of chromatophores ventrally (discontinuous in elongatus), and the 7 rays in the first dorsal fin (very rarely 7 in $G$. elongatus), also the larger eye and chromatophore above and behind the anus in G. Ruthensparri.

\section{GOBIUS PAGANELLUS L.}

Plate IV, Figs. 1-23.

Gobius paganellus is the common goby of the shore round Plymouth, and is to be found under stones at low water at spring tides all round the coast from near the dockyard opposite the Hamoaze and in Batten Bay to the more open bays of Bigbury and Cawsand; also on. Drake's Island in the Sound. From early spring to late summer the males may

Explanation of Plate IV. (Pectoral fins omitted except in, Fig. 24.) Gobius paganellus and Gobius niger.

Fia. 1.-Gobius paganellus, part of a layer of eggs laid on the under surface of a stone in a tank in the Laboratory. Eggs $2.6 \mathrm{~mm}$. long.

Fias. 2-19.-Gobius paganellus, eggs from same specimen as above drawn every day (all on the same scale) from the day of laying, March 28 th, until the day of hatching, April 14th. 1st egg $2.6 \mathrm{~mm}$. long.

Fia. 20.-Gobius paganellus, newly hatched, April 14th, length $4 \mathrm{~mm}$.

Frc. 21.-Gobius paganellus, hatched in small aquarium, $4.5 \mathrm{~mm}$. long.

Fra. 22.-Gobius paganellus, hatched in small aquarium, length $4.8 \mathrm{~mm}$.

Frc. 23.-Gobius paganellus, length $11.5 \mathrm{~mm}$. From the Sound inside the Breakwater, August 13, '17.

Fra. 24.-Gobius niger, length $12 \mathrm{~mm}$. Young Fish Trawl off Looe, August 13, '13. 
be seen guarding their eggs, which are attached to the under surface of stones in large masses, and the fish lay their eggs every year in a Laboratory tank. Some of these fish from Batten Bay were isolated in a tank in April, 1918, and several lots of eggs were obtained. The eggs on the stones were then put into small aërated aquaria standing in running water, and hatched out. In this way a drawing was made every day from the time of laying to the time of hatching.

The post-larval forms are caught occasionally in the tow-nets both inside and outside the Breakwater, and also further out in the Young Fish Trawl in 1913 and 1914. The eggs and newly hatched young are conspicuously larger than those of Gobius niger, which they closely resemble, and the bottom stage is not reached until a much greater length. The pigmentation in G. paganellus is not nearly so abundant as it is in $G$. niger.

Hefford (1910) describes the ova and newly hatched young and figures the latter; the specimen figured by him having the chromatophores much retracted. This measures $4.8 \mathrm{~mm}$. Those hatched in my small aquaria were $4 \mathrm{~mm}$. long and differ from Hefford's description and figure by having the ventral chromatophores behind the anus concentrated into one large mass which ramifies so that it nearly meets the dorsal chromatophore just above it, also in having a large yolk sac present. It is possible that these specimens were prematurely hatched as several died in the egg capsules, and the whole appearance was somewhat unhealthy. Older specimens measuring $4.8 \mathrm{~mm}$. almost exactly resemble Hefford's drawing, having the chromatophores separate and the yolk sac absorbed. These were 30 days old from the time of laying, and had been swimming about for some days.

The eggs are long and narrow with the apex ending in a rounded point, thus differing from the egg of $G$. niger, which is bluntly rounded at the apex. The usual size of the egg is about $2.5 \mathrm{~mm}$. long, but it varies a good deal in length and breadth. The same day that the egg is laid the blastoderm is nearly as large as the yolk and has become a mass of small cells. The next day it has spread round still more, the third day shows the embryo folded off and the neural groove conspicuous; on the fourth day the eyes appear, and on the fifth day eyes, ears, notochord and myotomes are all present. Up to the seventh day the head is nearly always below, but after this the embryo turns round and the head is uppermost. Heart and alimentary canal have now formed, and a little black pigment on the tail and at the eye margin. After this the young fish is very active in the egg capsule, pigment increases and on the 15th day has spread round the eye, but leaving the pupil still uncoloured; the air bladder is now pigmented and yellow pigment as well as black is present. On the 17 th day the pupil is black, 
the tail pigment concentrated into two large ventral and dorsal patches, and the corpuscles of the blood are red. At this stage the young fish hatched on the 19th day, measuring $4 \mathrm{~mm}$. It still possessed a large yolk sac, but its mouth was open. The yolk sac completely disappeared on the 30th day when the fish measured $4.8 \mathrm{~mm}$. At $4 \mathrm{~mm}$. when just hatched it closely resembles the newly hatched Gobius niger as described and illustrated by Petersen (1917), but is much larger, G. niger measuring only $2.5 \mathrm{~mm}$. It has a dorsal chromatophore on the tail when newly hatched, which in $G$. niger does not develop until the yolk sac has disappeared, and it measures $4.5 \mathrm{~mm}$. Gobius paganellus at $4.5 \mathrm{~mm}$. still has a large yolk sac, and in this way can be distinguished from $G$. niger of the same size. Throughout its post-larval life we find $G$. niger always more advanced than paganellus of the same size, and in the later stages possessing more pigment especially on the head.

Petersen describes $G$. niger as having only black pigment and a pale yellow tinge diffused over the whole of the body even at a length of $9 \mathrm{~mm}$., whereas there is a good deal of yellow pigment mixed with the black in $G$. paganellus even before hatching. The yellow is pale and there is no trace of an orange tinge.

The young of Gobius paganellus reared from the egg died before any metamorphosis took place. Young stages from 7 to $12 \mathrm{~mm}$. occurred in the tow-nets and occasionally in the Young Fish Trawl, the most usual size being about 10 to $12 \mathrm{~mm}$. These were caught in the Sound both from inside and outside the Breakwater, and in the Young Fish Trawl from Cawsand Bay and Whitsand Bay in 1914, and from Whitsand Bay, Bigbury Bay, New Grounds, Jennycliff Bay and Cawsand Bay in 1913.

In live specimens of $11 \mathrm{~mm}$. the body is very transparent with little pigment. The head is spread over with diffuse yellow, and there is a yellow spot. dorsally where in the very young it is black. At the base of the anal and caudal fins the black chromatophores are accompanied by reddish and yellow pigment. In specimens of $7 \mathrm{~mm}$. the black dorsal chromatophore on the tail has disappeared or there is only the merest trace of it, and there is still no black pigment on the head. There are 28 vertebræ, rarely 29,28 being typical also for $G$. niger. Fin rays, D VI 15 (rarely 14), A 12-13 (rarely 11).

At $7 \mathrm{~mm}$. the ventral chromatophores between the anus and tail are in a row, leaving a short space at about the level of the 10th vertebra from the end, the space not always being apparent owing to ramifications of the chromatophores which, however, are always slight. The fin rays of the second dorsal and anal are fully formed, but there is no trace of the first dorsal nor of the pelvies. The pectorals are mere flaps. The eye at this stage measures $0.32 \mathrm{~mm}$. across. There is a row of 
chromatophores from the throat to the anus, a large chromatophore above and behind the anus and dark pigment on the air bladder, which in live specimens is mixed with yellow. Very soon after this a dark star-like chromatophore appears in the auditory region, but it sometimes is not present until $11 \mathrm{~mm}$. In front of and below this there is sometimes another chromatophore, and there may be a small one above, but except for these there is no more head pigment, at least up to $12 \mathrm{~mm}$., and at that size the pelvic fins do not reach to the end of the air bladder and the whole fish is still completely in the post-larval condition, and unlike the typical $G$ : niger, which at the same length is almost like the adult. At $11 \mathrm{~mm}$. the pelvic fins reach to about the middle of the air bladder, and the pectorals reach not quite to the beginning of it. The air bladder itself is situated well in front of the middle line between the front of the head and the beginning of the tail fin. The eye measures $0.54 \mathrm{~mm}$. across. The first dorsal fin is well developed with all its rays present.

The more open water form of Gobius niger, the young of which occurs sometimes in the Young Fish Trawl, is more like G. paganellus than the typical form, as it is larger and does not undergo metamorphosis at so small a size. It can, however, be distinguished from paganellus by the black pigment on the dorsal surface of the tail and by the possession of more head pigment, although not so much as in the typical niger. Gobius paganellus can be distinguished from Aphya of the same size by the general shape, pigment, number of vertebræ and more developed condition of the fins, also by the position of the air bladder much further in front of the anus. It is, however, the species that comes nearest to Aphya of all the gobies.

\section{GOBIUS NIGER L.}

Plate IV, Fig. 24.

Gobius niger is found in the neighbourhood of Plymouth in the estuaries and along the coast, sometimes with Gobius paganellus, but usually on more muddy ground with fewer stones. The post-larval forms of about $10 \mathrm{~mm}$. are occasionally caught with the tow-nets in the Sound and also in the Young Fish Trawl from more open water. Petersen (1917) describes this species from the newly hatched young to the bottom stage, and finds that the small bottom stages are found in the more open parts of the fiords, although the eggs are laid near the shore in the same places as those of $G$. minutus and G. Ruthensparri. Ehrenbaum and Strodtmann (1904) found young gobies, which they attribute to $G$. niger, in the Western Baltic and, less abundantly, east of Bornholm. It is evident that $G$. niger occurs 
in the more open water as well as in the estuaries. In the Young Fish Trawl material in 1913 were a few specimens, all from open water with a depth of from 29 to 32 fathoms, which are very like $G$. niger, but remain longer in the post-larval stage than the inshore forms and are less pigmented. These agree exactly with the figure of Gobius niger from the Baltic given by Ehrenbaum and Strodtmann. The specimens from nearer inshore, on the other hand, are just like Petersen's, having very nearly attained the adult form at about $12 \mathrm{~mm}$., and the younger stages having more head pigment. Fage (1915) has shown that there is an inshore form and a more open water form of Gobius niger, the latter being the Gobius jozo L. of the Mediterranean. It seems probable that in this region we also have the two forms, one from more open water, which is the same as $G$. jozo, and is the species called niger by Ehrenbaum and Strodtmann, and one from nearer inshore, the Gobius niger proper, which is the same as Petersen's Scandinavian species. The young Gobius niger are well described and figured by Petersen, our own specimens from shallower water agreeing with his description. There are 28 vertebræ, fin rays, D VI 12-13, A 11-12. Before the bottom stage is reached the young under $10 \mathrm{~mm}$. has a black pigment spot on the dorsal surface of the tail, sometimes two, and the head has several dark chromatophores both dorsally and in the region of the otoliths. At $12 \mathrm{~mm}$. shape, fins and colouring are much more like the adult.

The specimens from deeper water from beyond Rame Head and the Eddystone have the same number of vertebræ and fin rays, but at $15 \mathrm{~mm}$. they still have the post-larval pelagic form, and there are not so many chromatophores on the head as in niger proper. These agree very well with Ehrenbaum's figure (1904, p. 108) from the Baltic, and it seems likely that they are both the Gobius jozo which Fage regards as a form of $G$. niger.

Gobius niger in the young stages can be distinguished from $G$. paganellus by the fewer fin rays, and by the black pigment on the dorsal surface of the tail; also by the greater number of chromatophores in the head region, especially in the inshore form, and this form also differs in always being more advanced in specimens of the same length, consequently reaching the bottom stage at a much smaller size.

\section{APHYA PELLUCIDA (NARDo).}

Plate III, Fig. 15.

Aphya is abundant round about Plymouth, but not many post-larval stages have been obtained. These were in Clark's material from the Young Fish Trawl in 1913, from the end of July to the beginning of 
September, most of the specimens occurring in August. They were most abundant in the surface hauls between 10 and 20 fathoms, but some were from beyond Rame Head and the Eddystone, where the depth was 25 to 30 fathoms. The largest haul (21 specimens) came from a surface haul off the Bell Buoy, Looe, at midnight, the depth over 10 fathoms. These measured from 12 to $16 \mathrm{~mm}$. in length.

The post-larval stages of Aphya can be distinguished from those of Gobius by their extremely narrow bodies, which give the fish an appearance of great length, and the very undeveloped state of the paired fins, which are not fully formed even at $20 \mathrm{~mm}$. The air bladder is very near the anus, which makes it appear further back than it really is, but it is actually situated further back than it is in most of the Gobius species. The anal fin has more rays ( 1 or 2 ) than the second dorsal, whereas in Gobius they are usually either equal or there are more in the dorsal. There are 27 vertebræ, which is less than in any British Gobius except Gobius scorpioides, which is now usually regarded as belonging to another genus Lebetus. Even in the adult the body is so transparent that the vertebræ can be seen through its walls and there is very little pigment. Several of the post-larval Gobius species, however, possess very little pigment, $G$. elongatus and $G$. minutus at $10 \mathrm{~mm}$. and up to about $14 \mathrm{~mm}$. having no head pigment, except a chromatophore in the region of the ear (which may be absent in elongatus), and a minute black mark at the angle of the lower jaw. These are both lacking in Aphya which has no head pigment in front of the throat. It is, however, to Gobius paganellus that it bears more close resemblance, for this goby has also very little pigment and only 28 or 29 vertebræ, but there are a few chromatophores on its head, which distinguish it in pigmentation from Aphya, and the broader body and well-developed fins would leave no doubt about the species.

The smallest specimen of Aphya seen measures $7 \mathrm{~mm}$., from Looe near the Bell Buoy. The greatest breadth, in the region of the air bladder, is $1.2 \mathrm{~mm}$., diameter of eye $0.36 \mathrm{~mm}$. The end of the air bladder is almost exactly half-way between the front of the head and the end of the body before the caudal fin. No pelvic fins developed, pectorals only minute flaps. Specimens of $8 \mathrm{~mm}$. are much the same, some of them having chromatophores ventrally in front of the anus and one above it. The chromatophore above the anus is present in nearly all from this size upwards, but the ventral chromatophores in front of the anus are only present in a few specimens except at the throat. A very fine membraneous larval fin is present in those up to about $20 \mathrm{~mm}$. from the throat to the anus. The alimentary canal is nearly straight and the air bladder is near the anus, nearer than in any of the Gobius species. The ventral row of unramified chromatophores behind the 
anus runs nearly to the end of the tail and has a slight tendency to interruption at the level of about the 9th vertebra from the end. In some this is hardly perceptible. On the lower half of the tail fin are a few black streaks. There are 27 vertebræ in all examined, fin rays, 13 in the second dorsal, rarely 12, 14 in the anal. Fage (1918) gives an equal number of rays in second dorsal and anal fins. The first dorsal, which in the adult consists of 5 rays, is only developed after it reaches a length of $16 \mathrm{~mm}$., and is therefore not shown in the figure which represents a specimen $11 \mathrm{~mm}$. long. Even up to $20 \mathrm{~mm}$. the first dorsal is not completely formed. The pectorals at this stage are short flaps without rays. The pelvics have not yet appeared.

The older specimens are much the same with the exception of the development of the paired fins and first dorsal. As the length increases the air bladder, which is still very near the anus, is rather nearer the front than it is in the very young stages, so that it is slightly in advance of the point half-way between the head and tail (exclusive of the tail fin), the tail growing faster than the fore part of the body. At $20 \mathrm{~mm}$. the rays of the pectoral fins and first dorsal fin have appeared and the pelvic fins are beginning, although still very short. The 5 rays of the first dorsal are set at the same distance apart, the last not being further away thàn the others, as is the case in Gobius.

It is thus seen that there is very little difference between post-larval and adult Aphya, the pigmentation being practically the same. The only important difference is in the growth of the fins. Post-larval stages of several species of Gobius resemble it, for these post-larvæ are pelagic and live part of their life near the surface of the sea, as Aphya does for the whole of its life. Thus we have a clear transparent body, usually with little pigment and eyes far apart on the sides of the head. Aphya remains so, but most of the Gobius species change their mode of life at a certain time and descend to live at the bottom. Their eyes are then on the dorsal surface instead of at the sides, and the varied pigmentation approximates to the colour of the sandy or muddy bottom. Aphya is a goby that has remained in the post-larval stage until maturity, and as far as we know it is an annual vertebrate and dies after reproduction.

Collett (1878) describes the young of Aphya in a general way, the description in every particular agreeing with our material. Ehrenbaum (1905) in describing the young from Scandinavia states that they occur in August, thus agreeing with the present records. 


\section{CRYSTALLOGOBIUS NILSSONI v. DUB AND KoR.}

Piate III, Fig. 16.

The young of Crystallogobius are common in the Young Fish Trawl in both 1913 and 1914, but chiefly the older stages of over $20 \mathrm{~mm}$. in length. Only one very young specimen was obtained, measuring about $9 \mathrm{~mm}$., which unfortunately was very badly preserved. This came from Rame, E. by N., 4 miles, the depth being 26 fathoms, in August, 1914. All the rest came from fairly deep water, chiefly from beyond Rame and the Eddystone. Clark (1913) found the eggs in June on the Eddystone grounds. The young occurred from May to August.

The young specimen of $9 \mathrm{~mm}$. shows at once the distinctive characters of Crystallogobius, the long second dorsal and anal fins being clearly defined. From these fins alone we can distinguish it from Aphya and from the various species of Gobius. The number of rays in the second dorsal is 19 or 20, in the anal 21. Thus, as in Aphya pellucida, we have more rays in the anal than in the second dorsal. The pelvic fins have not appeared and the pectorals are mere flaps without rays. The first dorsal, which is only present in the male and then has only two rays, is not developed for a long time. In the present specimen there is no pigment at all except in the eye and air bladder, but we cannot be sure that this is typical as this is the only small specimen found. In rather older examples pigment similar to the adult is present. At $20 \mathrm{~mm}$. the pelvics in the male have just begun to develop, and the pectorals are smaller than they are in Aphya of the same size, but no pelvics show in the females even at $25 \mathrm{~mm}$., when ovaries are well advanced. Only after $30 \mathrm{~mm}$. are the pelvics developed in the female and are then hardly distinguishable. There are 30 vertebræ in Crystallogobius, but it is so clearly distinguished from Gobius by other features that there is no fear of confusion with G. pictus and G. Jeffreysii, which also possess 30 vertebræ.

Collett (1878) describes briefly the young of Crystallogobius, and Fage (1918)' found post-larval forms from the coasts of Brittany of $14 \mathrm{~mm}$. In these the pigment was present along the base of the anal fin, and the characteristic ventral line of pigment from the throat to the anus was present, a large chromatophore at the posterior end of the air bladder and a touch of pigment on the caudal fin. In these he describes the ovary as easily recognisable.

A key to the species of young Gobius, Aphya and Crystallogobius as above described is here given, based principally on the typical number of vertebræ and fin rays. When these vary a footnote is given showing the variations. 
A KEY TO THE SPECIES OF YOUNG GOBIUS, APHYA AND CRYSTALLOGOBIUS BASED ON THE NUMBER OF VERTEBRÆ AND FIN RAYS AS TYPICALLY PRESENT.

I. 33 Vertebræ, fin rays D VI 11-12, A 11-12.

II. 32 Vertebræ.
A. Fin rays D VI 9-10, A 9-10.
Gobius elongatus. $\dagger$
B. Fin rays D VII 11 , A 11 .
Gobius Ruthensparri.

III. 31 Vertebræ, fin rays D VI 9-10, A 9-10. Gobius microps. IV. 30 Vertebræ.

A. Fin rays D VI 9-10, A 9-10.

a. Spot at base of last ray of 1st dorsal fin:

Gobius Jeffreysii.

b. No spot at base of last ray of 1st dorsal fin (up to $14 \mathrm{~mm}$.)

Gobius pictus.§

B. Fin rays D II (in male only) 20, A. 21.

V. 28 Vertebræ.

Crystallogobius Nilssoni.

A. No dorsal pigment on tail, fin rays D VI 14-15, A 12-13.

Gobius paganellus.§

B. Dorsal pigment on tail, fin rays D VI 12-13, A 11-12.

VI. 27 Vertebræ, fin rays D V 12-13, A 14 .

Gobius niger.\$

Aphya pellucida.

\section{LITERATURE.}

1917. Allen, E. J. Post-Larval Teleosteans collected near Plymouth during the summer, 1914. Jour. Mar. Biol: Assoc., N.S., XI, No. 2.

1911. Boulenger, E. G. Remarks on Two Species of Fishes of the Genus Gobius, from Observations made at Roscoff. Proc. Zool. Soc., London, 1911.

1862. Canestrini, G. I Gobii del Golfo di Genova. Arch. Zool., I, 2.

1913. Clark, R. S. General Report on the Larval and Post-Larval Teleosteans in Plymouth Waters. Jour. Mar. Biol. Assoc., N.S., X, No. 2.

* Rarely 34 vertebræ, very rarely 32 .

$\dagger$ Rarely 30 to 33 , 1st dorsal rarely VII, second dorsal and anal rarely 11 .

$\ddagger$ Rarely 30 vertebræ. 
1878. Collett, $R$. On Latrunculus and Crystallogobius, two remarkable Forms of Gobioid Fishes. Proc. Zool. Soc., London, 1878.

1902. — Meddelser am Norges Fiske. 1 Aarene, 1884-1901, I, 1902.

1904. Ehrenbaum, E., and Strodtmann, S. Eier und Jungendformen der Ostseefische. Wiss. Meeresunt, Helgoland, VI.

1905. Ehrenbaum, E. Eier und Larven von Fischen. Nordisches Plankton, Part I, IV.

1914. Fage, L. Sur le Gobius minutus Pallas et quelques Formes Voisines. Bull. Soc. Zool. de France, Vol. XXXIX, 1914.

1915. - Sur quelques Gobius méditerranéans (G. Kneri Stndr., G. elongatus Canestr., G. niger L.). Bull. Soc. Zool. de France, Vol. XL, 1915.

1918. — Report on the Danish Oceanographical Expeditions, 1908-1910, to the Mediterranean and Adjacent Seas. .Vol. II, Shore Fishes, 1918.

1892. Guitel, F. Observations sur les Mœurs de Gobius minutus. Arch. Zool., Paris, 2 S., X.

1910. Hefford, A. E. Notes on Teleostean Ova and Larvæ observed at Plymouth in Spring and Summer, 1909. Jour. Mar. Biol. Assoc., N.S., IX.

1897. Holt, E. W. L. Note. Jour. Mar. Biol. Assoc., Vol. V, N.S., 1897. P. 89.

1901. Holt, E. W. L., and Byrne, L: W. The British and Irish Gobies. Rep. on the Sea and Inland Fisheries of Ireland. Scientific Investigations, 1901.

1918. Lebour, M. V. The Food of Post-Larval Fish. Jour. Mar. Biol. Assoc., XI, No. 4, 1918.

1892. Petersen, C. G. J. On the Eggs and Breeding of our Gobiidæ. Rep. Danish Biol. Stat., 1891-92, II.

1917. — On the Development of our Common Gobies (Gobius) from the Egg to the Adult Stages, etc. Rep. Danish Biol. Stat., XXIV, 1916.

1911. Sanzo, L. Destribuzione delle papille cutanee (organi ciatiformi) e suo valore sistematico nei Gobi? Mitth. Zool. Stat., Naples, XX, 1911. 